\title{
Faktor-Faktor yang Mempengaruhi Minat Menggunakan Layanan Financial Technology Peer To Peer Lending Syariah
}

\author{
Henny Triyana Hasibuan ${ }^{1}$ \\ Fakultas Ekonomi dan Bisnis \\ Universitas Udayana, Indonesia
}

\begin{abstract}
Surel : henny_triyana@unud.ac.id
ABSTRAK

Tujuan penelitian ini adalah untuk melihat faktor-faktor yang mempengaruhi minat pengguna layanan fintech peer to peer lending syariah dengan menggunakan model Unified Theory Of Acceptance and Use Of Technology 2 (UTAUT2). Variabel eksogen dalam penelitian ini adalah performance expectancy, effort Expectancy, Social influence, facilitating condition, price value, hedonic motivation dan habit, sedangkan variabel endogen adalah behavior intention. Pengumpulan data dilakukan secara dengan menyebarkan kuesioner mempergunakan google formulir. Teknik analisis data yang digunakan adalah Structural Equational Modeling (SEM). Hasil penelitian menunjukkan bahwa variabel performance expectancy, social Influence, Hedonic Motivation dan Habit tidak berpengaruh terhadap minat (behavior intention) menggunakan layanan fintech peer to peer landing syariah sedangkan variabel Effort Expectancy, Facilitating Condition dan Price Value berpengaruh positif terhadap minat (behaviour intention) menggunakan layanan fintech peer to peer lending syariah.
\end{abstract}

Kata Kunci: UTAUT2; Behavior intention; Financial Technology Peer To Peer Lending Syariah; SEM.

\section{Factors Affecting Interest in Using Sharia Peer To Peer Lending Financial Technology Services}

\section{ABSTRACT}

The purpose of this study was to see the factors that influence the interest of users of Islamic peer to peer lending services using the Unified Theory Of Acceptance and Use Of Technology 2 (UTAUT2) model. The exogenous variables in this study are performance expectancy, effort expectancy, social influence, facilitating conditions, price value, hedonic motivation and habit, while the endogenous variable is behavior intention. The data was collected by distributing questionnaires using google forms. The data analysis technique used is Structural Equational Modeling (SEM). The results showed that the variables of performance expectancy, social influence, hedonic motivation and habit had no effect on behavior intention to use Islamic peer to peer landing fintech services, while the variables Effort Expectancy, Facilitating Condition and Price Value had a positive effect on behavior intention using Islamic peer to peer lending services.

Keywords: $\quad$ UTAUT2; Behavior intention; Financial Peer To Peer Islamic Lending; SEM.

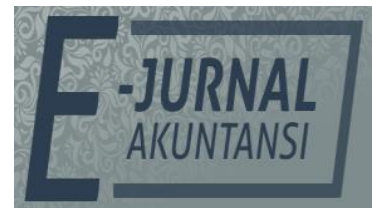

e-ISSN 2302-8556

Vol. 31 No. 5

Denpasar, Mei 2021

Hal. 1201-1215

DOI:

10.24843/EJA.2021.v31.i05.p10

PENGUTIPAN:

Hasibuan, H.T. (2021).

Faktor-Faktor yang

Mempengaruhi Minat

Menggunakan Layanan Financial Technology Peer To

Peer Lending Syariah. E-Jurnal Akuntansi, 31(5), 1201-1215

RIWAYAT ARTIKEL:

Artikel Masuk:

26 Februari 2021

Artikel Diterima:

24 Mei 2021

Artikel dapat diakses : https://ojs.unud.ac.id/index.php/Akuntansi/index 


\section{PENDAHULUAN}

Peer to peer landing atau yang biasa disebut $p 2 p$ lending merupakan penyelenggaraan layanan jasa keuangan yang prakteknya mempertemukan pemberi pinjaman dengan penerima pinjaman melalui mekanisme online. Pada dasarnya $p 2 p$ lending memiliki konsep yang sangat mirip dengan online market place yang menyediakan wadah sebagai tempat dipertemukannya penjual dan pembeli, tetapi $p 2 p$ lending mempertemukan pemberi pinjaman dengan peminjam. Adanya $p 2 p$ lending semakin mempermudah masyarakat untuk memberikan pinjaman atau mengajukan pinjaman untuk berbagai kepentingan tanpa menggunakan jasa dari lembaga keuangan yang syah sebagai perantara. Kemudahan yang ditawarkan oleh $p 2 p$ lending dibandingkan dengan pelayanan perbankan masih terbatas, persyaratan dan prosedur yang lebih banyak serta masih banyaknya masyarakat Indonesia yang belum dilayanani oleh perbankan menjadi sebab daya tarik masyarakat dengan kehadiran $p 2 p$ lending.

Penyelenggara $p 2 p$ lending pertama kali muncul tahun 2017 (OJK2018). Sampai dengan tahun 2020 sebanyak 149 perusahaan $p 2 p$ lending sudah terdaftar dan memiliki izin usaha hadir di Indonesia, dari jumlah tersebut sebanayak 35 perusahaan fintech $p 2 p$ lending beroperasi dengan memiliki izin usaha penuh dari regulator. Perkembanan $p 2 p$ lending dari tahun 2019 sampai tahun 2020 terdapat pada Tabel 1.

Tabel 1. Perkembangan P2p lending di Indonesia Tahun 2019-2020

\begin{tabular}{llll}
\hline Keterangan & Tahun 2019 & Tahun 2020 & $\begin{array}{l}\text { Kenaikan/ } \\
\text { (Persentase } \\
\text { Penurunan) }\end{array}$ \\
\hline Nilai Tumbuh & 81,49 Triliyun & 155,9 Triliyun & 91,3 \\
Dana Out Standing & 13,4 Triliyun & 15,31 triliyun & 16,43 \\
Lender & 605,935 & 716,963 & 18,32 \\
Borrower & 18,56 juta & 43,56 Juta & 134,59 \\
\hline
\end{tabular}

Sumber: Kontan.co.id

Pada Tabel 1, nilai tumbuh untuk penyaluran pinjaman 2020 mengalami kenaikan sebesar 91,3 persen dibandingkan tahun 2019, dana out standing (dana yang beredar) mengalami kenaikan 16,43 persen, Jumlah lender (pemberi pinjaman) mengalami kenaikan sebesar 18,32 persen serta jumalah penerima pinjaman (borrower) juga mengalami kenaikan sebesar 134,59 persen. Dari data tersebut dapat disimpulkan bahwa masyarakat Indonesia pada masa pandemi Covid 19 sangat membutuhkan dana, ini terlihat dalam Tabel 1 kenaikan borrowed naik 134,59 persen dan salah satu sumber dana berasal dari $p 2 p$ lending. Kenaikan yang jumlah peminjam tersebut tidak luput dari kemudahan bagi borrower seperti hanya bermodalkan Kartu Tanda Penduduk (KTP), Kartu keluarga (KK) mereka dapat memperoleh pinjaman tanpa agunan seperti hal nya bila melakukan pinjaman di lembaga keuangan lainnya.

Perkembangan $p 2 p$ lending tidak luput dari makin maraknya perkembangan $p 2 p$ lending yang illegal. Menurut OJK (2020) ada banyak perusahaan fintech $p 2 p$ lending dengan ciri-ciri (1) tidak memiliki legalitas, (2) mengenakan bunga, biaya dan denda yang sangat tinggi (3) proses penagihan yang tidak ber etika (4) akses data pribadi berlebihan (5) pengaduan tidak tertangani (6) lokasi kantor tidak jelas (7) mengirimkan pesan singkat spam. 
Kasus-kaus pinjaman $p 2 p$ lending sempat menjadi pemberitaan yang cukup meluas. Berdasarkan data Lembaga Bantuan (LBH) Jakarta pada tahun 2019 terdapat 4.500 aduan tentang fintech $p 2 p$ lending, sementara satgas waspada investasi $p 2 p$ lending melaporkan sebanyak 683 entitas $p 2 p$ lending yang telah dihentikan operasinya. Pelanggaran yang dilakukan oleh $p 2 p$ lending tidak hanya dilakukan oleh penyelenggara $p 2 p$ lending ilegal tetapi juga dilakukan oleh $p 2 p$ lending yang telah terdaftar di OJK. Sanksi berupa pemblokiran situs dan akses rekening yang dilakukan oleh OJK dinilai kurang tepat, sehingga langkah yang dilakukan selanjutnya adalah memberikan sosialisasi dan merilis daftar $p 2 p$ lending yang terdaftar di OJK. OJK bekerjasama dengan AFPI (Assosiasi Fintech Pendanaan Indonesia) membentuk task force yaitu memantau pergerakan fintech illegal melalui aplikasi fintech illegal dan melaporkannya ke satgas waspada investai dan bareskrim cyber crime (Kontan.co.id, 2019). Upaya untuk minimalisir terhadap resiko tersebut membuat masyarakat harus jeli dalam memilih flatform $p 2 p$ lending yang digunakan dalam melakukan peminjaman atau pembiayaan

Kehadiran $p 2 p$ lending tidak serta merta disambut begitu saja karena sebagian pemeluk agama islam di Indonesia yang religius menginginkan kehadiran $p 2 p$ lending syariah. Keberadaan $P 2 p$ lending syariah yang terdaftar di OJK secara eksplisif menandai adanya perbedaan dengan fintech $p 2 p$ lending berbasis konvensional. Perbedaan tersebut dilihat dari segi proses, jenis akad, dan system bagi hasil. P2p lending syariah tidak hanya menawarkan pinjam meminjam sesuai syariah tetapi juga sebagai alternatif investasi dengan keuntungan melalui mekanimesme bagi hasil.

Penyelenggara Fintech $p 2 p$ lending syariah setiap tahun berkembang tetapi tidak sebanding dengan perkembangan dengn $p 2 p$ lending konvensional walaupun mayoritas penduduk Indonesia memeluk agama islam. Berdasrkan data OJK tahun 2020 sebanyak 13 penyelenggara $p 2 p$ lending, 12 diantaranya ber flatform syariah dan 1 merupakan Unit usaha Syariah. Dana yang tesalur selama tahun 2020 sebesar Rp 4 Triliyun (Financial Bisnis.com, 2020).

Pendekatan ilmiah yang dapat dipergunakan dalam penelitian ini melalui model UTAUT2. Model UTAUT2 merupakan metode yang paling tepat dipergunakan dalam penelitian bidang IT dan penerimaan sebuah produk baru berbasis teknologi pada suatu kelompok karena telah andal dan banyak digunakan. Penelitian ini menggunakan teori UTAUT2 dikembangkan oleh Ventakesh et al (2012) yang menjelaskan 7 faktor yang mempengaruhi minat menggunakan (behavior intention) terhadap terhadap teknologi informasi yang terdiri harapan kinerja (performance expectancy), harapan usaha (effort expectancy), pengaruh sosial (social influence) dan memfasilitasi kondisi (facilitating condition), Price value, Hedonic Motivation danHabit.

Penelitian ini mengacu pada penelitian penelitian sebelumnya yaitu penelitian V.N Vadillah (2017), Veronica Yuniarti dan Wiwik Hidajah Ekowati (2019) yaitu minat menggunakan layanan financial technology peer to peer lending dengan menggunkana teori Technologi Acceptance Model (TAM) dan Innovation Diffusion Theory (IDT). Selain itu penelitian ini juga mengacu pada panelitian Ascaryo Putra dan Hendratmoko (2017) tentang minat menggunakan layanan peer to peer lending dengan menggunakan teori UTAUT dan mempergunakan 
variabel Performance Expectancy, Effort Expectancy, Social Inluence, Trust, Reputation danSelf Efficacy.

Perbedaaan penelitian ini dengan penelitian sebelumnya yaitu (1) penelitian ini menggunakan teori UTAUT 2 dengan variabel eksogen terdiri dari variabel harapan kinerja (performance expectancy), harapan usaha (effort expectancy), pengaruh sosial (social influence) dan memfasilitasi kondisi (facilitating condition), Price value, Hedonic Motivation dan habit terhadap minat menggunakan (Behavior intention) layanan peer to peer syariah, (2)penelitian ini mempergunakan sampel penelitian adalah pengguna layanan $p 2 p$ lending syariah di Indonesia sedangkan penelitian sebelumnya mengggunakan sampel penelitian $p 2 p$ lending konvensional (3) penelitian tentang minat menggunakan layanan $p 2 p$ lending syariah belum pernah ada yang melakukan. Alasan-alasan tersebut, membuat peneliti termotivasi untuk melakukan penelitian dengan judul Faktor-Faktor Yang Mempengaruhi Minat Menggunakan Layanan Financial Technology Peer to Peer lending Syariah.

Model UTAUT2 merupakan sebuah model penerimaan teknologi dari Ventakesh, Thong \& Xu (2012). Model ini menjelaskan bagaimana minat dan perilaku pengguna terhadap penerimaan sutu teknolohgi dipengaruhi oleh beberapa faktor seperti Performance Expectasi (PE), Effort Expectancy (EE), Social Influence (SI), Facilitating Condition (FC), Price Value (PV), hedonic Motivation (HM), dan Habit $(\mathrm{H})$. Model ini menjelaskan bahwa penerimaan suatu teknologi berdasarkan sisi pengguna, menjadi lebih baik dengan persentase perbaikan dari 56 persen menjadi 74 persen, aspek penerimaan berupa niat perilaku penggunaan dengan persentase dari 40 persen menjadi 52 persen(Ventakes et al, 2012)

Faktor pertama yang mempengaruhi minat menggunakan layanan $p 2 p$ lending syariah adalah Ferformance Expectancy (FE). Ferformance Expectancy memiliki pengaruh yang signifikan terhadap niat menggunakan sistem tersebut (Ventakesh et al; 2003). Penggunaan suatu sistem oleh seseorang jika mereka merasa sistem yang digunakan mampu memberi rasa aman dan dapat membuat seseorang melakukan pekerjaannnya lebih cepat. Hasil penelitian Ascaryo Putro \& Hendratmoko (2019), Ramdhani et al (2017), Chang et al (2019) Pertiwi \& Ariyanto (2017) menunujukkan bahwa performance expectancy berpengaruh signifikan terhadap minat menggunakan layanan teknologi.

Seseorang yang mempergunakan layanan fintech $p 2 p$ lending syariah yang memberikan keuntungan seperti kecepatan layanan, keamanan, dan kenyamanan dan membuat seseorang merasakan transasksi pembayaran menjadi lebih efektik, efsien dan ekonomis dibandingkan dengan layanan fintech lainya. Berdasarkan teori UTAUT2 dan temuan-temuan hasil penelitian maka hipotesis penelitian adalah.

$\mathrm{H}_{1}$ : Performance Expectancy berpengaruh posisitf terhadap minat menggunakan layanan fintech $p 2 p$ lending syariah.

Faktor kedua yang mempengaruhi penggunaan layanan $p 2 p$ lending syariah adalah Effort Expectancy (EE). Effort Expectancy adalah tingkat kemudahan terkait dengan penggunaan sistem informasi (Ventakesh et al, 2003). Ventakesh (2003) menyatakan bahwa effort expectancy merupakan tingkat kemudahan yang berhubungan dengan suatu sistem. Jika sistem tersebut mudah dipergunakan 
maka usaha yang dilakukan tidaklah terlalu tinggi dan sebaliknya jika suatu sistem sulit dipergunakan, maka diperlukan usaha yang tinggi untuk menggunakannya. Penelitian yang dilakukan oleh Ascaryo Putro \& Hendratmoko (2019), Zulhaida \& Giri (2017), Faridhal (2019), Amrullah \& Anjar (2018), Agustin \& Mulyani (2018), Prasetyo (2017), Muhammad \& Salina (2018) menunjukkan hasil bahwa ekspektasi usaha berpengaruh terhadap minat untuk menggunakan layanan sistem informasi. Fitur aplikasi fintech yang sederhana menjadikan fintech $p 2 p$ lending syariah lebih mudah untuk dipahami dan praktis untuk digunakan. Kemudahan penggunaan fintech $p 2 p$ lending syariah dalam proses pinjam meminjam uang secara online tanpa jaminan. Berdasarkan teori utaut 2 dan didukung oleh hasil penelitian empiris lainnya maka hipotetsis 2 dalam penelitian adalah sebagai berikut.

$\mathrm{H}_{2}$ : Effort Expectancy berpengaruh positif terhadap minat menggunakan layanan fintech $p 2 p$ lending syariah.

Menurut model UTAUT 2 faktor ke tiga yang mempengaruhi minat menggunakan suatu system adalah social Influence. Ventakesh et al (2003) menyatakan social influence berpengaruh terhadap behavioral intention. Zhou et al (2010) juga menyatakan bahwa social influence merupakan tingkat dimana individu mengangggap orang lain mempengaruhi dirinya dalam menggunakan teknologi. Hasil penelitian sebelumnya yaitu Zulhaida \& Giri (2017), Gayati \& Kusyanti (2017), Chang et al (2019), Agustin \& Mulyani (2018), Suwandi \& Elvira (2018) serta Amrullah \& Anjar (2018) menunjukkan bahwa social influence berpengaruh terhadap minat menggunakan suatu system informasi. Hal ini dapat diartikan bahwa salah satu faktor yang mempengaruhi seseorang menggunakan teknologi baru disebabkan karena mendapatkan dukungan dan anjuran dari orang-orang terdekatnya seperi dari keluarga, kerabat, teman dan masyarakat yang mempergunakan fintech $p 2 p$ lending syariah. Berdasarkan teori utaut2 dan didukung oleh hasil penelitian empirilainnya maka hipotesis penelitian ini sebagai berikut.

$\mathrm{H}_{3}$ : Social influence berpengaruh posisitf terhadap minat menggunakan layanan fintech $p 2 p$ lending syariah.

Faktor keempat yang mempengaruhi miat menggunakan suatu system adalah facilitating Condition. Facilitating condition dapat diartikan sebagai tingkat dimana seseorang percaya bahwa infastruktur dan sumber daya tersedia untuk mendukung penggunaan aktual sistem informasi (Ventakesh et al, 2003). Hasil penelitian lainnya yang mendukung hipotesis ini adalah Nugroho et al (2017), Nurisha et al (2018), Chang et al (2019). Facilitating condition dalam menggunakan layanan fintech $p 2 p$ lending syariah menunjukkan layanan teknologi finansial yang didukung oleh infra struktur dan teknis yang memadai seperti smart phone berbasis android, jaringan internet, kuota dan pulsa internet. Penggunaan teknologi financial mengharuskan pengguna untuk memiliki ketrampilan khusus seperti mengoperasikan smartphone berbasis android dan menghubungkannya ke layanan internet sehingga memerlukan biaya akses data pada saat mengoperasikan sistem.

$\mathrm{H}_{4}$ : Facilitating Condition bepengaruh positif terhadap minat menggunakan layanan fintech $p 2 p$ lending syariah. 
Faktor ke lima yang mempengaruhi minat menggunakan layanan Fintech $p 2 p$ lending syariah menurut teori UTAUT 2 adalah Price Value. Price value merupakan nilai yang dirasakan, yang sering dianggp seagai indikator penting dalam memprediksi perilaku pembeli yang mempengaruhi keunggulan kompetitif perusahaan. Menurut Ventakesh et al (2012) Price Value memiliki efek positif pada minat ketika konsumen merasakan manfaat menggunkan teknologi lebih besar dari pada biaya moneter penggunaan tersebut. Hasil penelitian Nugroho et al (2017), Nurisha et al (2018), Budiartho (2018), Chang et al (2019), Putra \& Arianti (2013), Kurniabudi \& Assegaf (2016) menunjukkan bahwa price value berepengaruh terhadap minat mengunakan layanan suatu system informasi. Price value dalam penelitian ini merupakan menggunaan layanan $p 2 p$ lending syariah bermanfaat disebabkan karena pinjaman dapat diperoleh tanpa harus menggunakan agunanan. Berdasarkan uraian tersebut maka hipotesis yang diajukan sebagai berikut.

$\mathrm{H}_{5}$ : Price Value berpengaruh positif terhadap minat menggunakan layanan $p 2 p$ lending syariah.

Faktor ke enam yang mempengaruhi minat menggunakan layanan Fintech $p 2 p$ lending syariah beradasarkan teori UTAUT2 adalah Hedonic Motivation. Ventakesh et al (2012) menyatakan adopsi teknologi dipengaruhi secara signifikan oleh motivasi hedonis. Lebih lanjut (Brown \& Ventakest; 2005) menyatakan bahwa hedonic matovation merupakan kesenangan atau kebanggaan yang didapat dari penggunaan suatu technology dan telah menjadi suatu hal yang penting untuk menentukan penerimaan technology baru. Pernyataan ini didukung oleh hasil penelitian Budiarto (2018), Nugroho Kusin \& Sudarmawan (2018), Chang et al (2019), Lubis \& Rahmawati (2019) menyatakan hedonic motivation secara signifikan mempengaruhi bahavioral intention. Hedonic Motivation dalam penelitian ini adalah pengguna layanan $p 2 p$ lending syariah merupakan suatu kesenangan berkaitan dengan sikap religious. Sikap Religius kerena pinjaman tidak mengandung unsur riba tetapi berdasarkan akad yang disepakati. Berdasarkan uraian tersebut maka hipotesis yang diajukan adalah sebagai berikut.

$\mathrm{H}_{6}$ : Hedonic Motivation bepengaruh terhadap minat menggunakan (behavioral Intention) layanan $p 2 p$ lending syariah.

Faktor ke tujuh yang mempengaruhi minat menggunakan layanan fintech $p 2 p$ lending syariah menurut model UTAUT 2 adalah Habit. Menurut Kon \& Malhotra (2005) habit itu sama dengan otomatisasi sedangkan menurut Ventakest el al (2012) habit merupakan pembangunan persepsi yang mencerminkan hasil dari pengalaman sebelumnya yang dalam hal ini berkaitan dengan sistem informasi. Hasil penelitian Ramdhani et al (2017), Nurisha et al (2018), Faridhal (2019), Gayatri et al (2017), Chang et al (2019), Lubis \& Rahmawati (2019) mendukung model UTAUT 2 yaitu habit berpengaruh terhadap minat menggunakan (behavior intention) layanan suatu system informasi. Habit didalam hal ini merupakan sebuah kebiasaan mempergunakan layanan informasi dengan mempergunakan internet. Berkaiatan dengan pinjaman yang diperoleh dengan mudah serta tidak mengandung unsur yang bertentangan dengan syariat islam. Berdasarkan uraian, maka hipotesis yang dapat disimpulkan sebagai berikut. 
$\mathrm{H}_{7}$ : Habit bepengaruh positif terhadap minat menggunakan layanan $p 2 p$ lending syariah.

\section{METODE PENELITIAN}

Peneltian ini menggunakan pendekatan kuantitatif. Tujuan penelitian ini adalah untuk mengetahui faktor-faktor yang mempengaruhi minat individu dalam menggunakan fintech $p 2 p$ lending syariah. Populasi merupakan keseluruhan kelompok orang, peristiwa atau hal-hal menarik yang ingin diteliti (Sekaran \& Baugie; 2017). Populasi dalam penilitian ini adalah individu atau pengusaha yang menggunakan layanan financial technologi peer to peer lending syariah yang bertindak sebagai peminjam. Sampel merupakan bagian dari populasi (Sakaran \& Baugie, 2017). Penarikan sampel dilakukan dengan cara purposive sampling yaitu teknik penarikan sampel yang tidak memberi peluang atau kesempatan yang sama bagi setiap unsur atau anggota populasi untuk dipilih menjadi sampel (Sugiyono, 2016:84). Sampel dari penelitian ini adalah seluruh pengguna layanan fintech peer to peer lending syariah yang pernah menggunakan layanan fintech $p 2 p$ lending syariah. Penelitian ini menyebarkan sebanyak 200 kuesioner kepada responden yang menggunakan layanan $p 2 p$ lending syariah di Indonesia.

Jenis data yang dipergunakan adalah data primer meliputi data yang berhubungan dengan pernyataan responden terhadap penggunaan layanan fintech $p 2 p$ lending syariah. Data primer bersumber dari jawaban responden dengan menyebarkan kuesioner. Metode survei dipergunakan dalam penelitian ini secara langsung melalui online berdasarkan kuesioner dengan indikator dan variabel yang disusun berdasarkan model UATUT 2, hasil dari kuesione dianalisis menggunakan Structural Equational Modeling (SEM) dengan aplikasi AMOS.

Penelitian ini menggunakan variabel eksogen yang terdiri dari Performance Expectancy $\left(\mathrm{X}_{1}\right)$, Effort Expectancy $\left(\mathrm{X}_{2}\right)$, Social Influence $\left(\mathrm{X}_{3}\right)$, Facilitating Condition $\left(\mathrm{X}_{4}\right)$, Price Value $\left(\mathrm{X}_{5}\right)$, Hedonic Motivation $\left(\mathrm{X}_{5}\right)$, dan Habit $\left(\mathrm{X}_{6}\right)$, sedangkan variabel endogen dalam peneliian ini adalah minat menggunakan (Behavior intention) layanan fintech $p 2 p$ lending syariah $(\mathrm{Y})$. Penelitian ini menggunakan skala likert (lima) point mulai dari Sangat Setuju (SS), Setuju (S), Netral (N), Tidak Setuju (TS) dan Sangat Tidak Setuju (STS). Menurut (Sugiyono, 2017; 158) skala likert digunakan untuk mengukur sikap seseorang atau sekelompok orang terhadap fenomena sosial.

\section{HASIL DAN PEMBAHASAN}

Kuesioner yang berhasil disebarkan sebanyak 200 kuesioner dan disebarkan secara online melalui aplikasi google form, dengan kriteria, responden yang menggunakan layanan $p 2 p$ lending syariah. Dari hasil penyebaran kuesioner sebanyak 173 kuesioner berhasil dikembalikan, tetapi kuesioner yang layak untuk dapat diolah sebanyak 143 kuesioner dan sebanyak 30 kuesioner dinyatakan tidak memenuhi kriteria sebagai data disebabkan responden bukan pemakai $p 2 p$ lending syariah dan data kuesioner tidak lengkap pengisiannya.

Menurut Ghozali (2013) indikator dari sebuah varibel disebut valid jika nilai loading factor $>0,50$ jika salah satu indikator memiliki nilai loading factor < 0,50 maka indikator tersebut harus dibuang karena mengindikasikan indikator 
tidak bisa digunakan untuk mengukur variabel laten secara tepat. Uji reabilitas dilakukan untuk memastikan dan mengkonfirmasikan ketetapan dan kehandalan variabel. Uji reabilitas mempergunakan rumus Variance Extracted $(A V E)$. Indikator dari nilai varibael disebut realibel jika AVE $>0.50$ dan nilai AVE kurang dari 0,50 menunjukkan indikator memiliki nilai rata-rata tingkat eror yang tinggi (Ghozali,2013). Cronchbach Alpha dipergunakan untuk mengetahui tingkat reabilitas dari variabel. Instrumen penelitian dikatakan realibel jika memiliki nilai cronchbach alpha $>0,60$. Hasil uji validitas dan reabilitas maka nilai AVE dan Cronchbach Alpha terdapat dalam Tabel 2.

Tabel 2. Uji Validitas dan Reabilitas

\begin{tabular}{lcc}
\hline Variabel & $\begin{array}{c}\text { AVE } \\
\text { (Variance Extrated })\end{array}$ & $\begin{array}{c}\text { Cronchbach } \\
\text { Alpha }\end{array}$ \\
\hline BI & 0,67 & 0,80 \\
PE & 0,87 & 0,92 \\
EE & 0,59 & 0,74 \\
SI & 0,67 & 0,72 \\
FC & 0,90 & 0,82 \\
PV & 0,78 & 0,71 \\
HM & 0,69 & 0,69 \\
H & 0,92 & 0,70 \\
\hline
\end{tabular}

Sumber: Data Penelitian , 2021

Pada Tabel 2, menunjukkan bahwa hasil uji validitas dan reabilitas diperoleh hasil keseluruhan variabel telah memenuhi nilai standar dari AVE dan cronchbach Alpha sehingga keseluruhan varibel dapat dikatakan valid dan realibel.

Analisis selanjutnya yaitu melakukan analisis determinasi untuk mengetahui seberapa besar kontribusi variabel eksogen terhadap variabel endogen (Ghozali 2008). Dalam penelitian ini objek penelitian yaitu pengguna $p 2 p$ lending syariah dengan menggunakan teori UTAUT 2 dengan model behavioral intention. Hasil analisis determinasi terdapat pada Tabel 3.

Tabel 3. Koefisien determinasi (R Square)

\begin{tabular}{ll}
\hline Varibel & R Square \\
\hline Behavioural Intention & 0.73 \\
\hline
\end{tabular}

Sumber: Data Penelitian , 2021

Pada Tabel 3, nilai koefisien determinasi variabel behavioral intention sebesar 0,73. Hal ini menandakan bahwa variabel didalam model mampu mengambarkan behavioral intention sebesar 73 persen dan sisanya dipengaruhi oleh variabel lain yang tidak diteliti. Nilai path koefisien menunjukkan tingkat signifikansi dalam pengujian hipotesis (Abdillah W H, 2015:197). Hipotesis dilakukan dengan melihat estimasi path koefisien dan nilai $t$ statistic dengan nilai signifkansi pada $a=5$ persen. Jika nilai $t$ statistic leih besar dari 1,64 untuk hipotesis satu ekor (one tailed) artinya hipotesis diterima, sedangkan apabila nilai $\mathrm{t}$ statistic kurang dari 1,64 maka hipotesis ditolak. Berikut merupakan nilai path coefisient dalam Tabel 3,

Tabel 4. hasil Uji Path Coeficient

\begin{tabular}{lllc}
\hline Hubungan Jalur & Loding Factors & T-Statistic & Keterangan \\
\hline $\mathrm{PE} \rightarrow \mathrm{BI}$ & 0,0134 & 0,1764 & $H_{1: \text { ditolak }}$ \\
$\mathrm{EE} \rightarrow \mathrm{BI}$ & 0,1651 & 2,1852 & $H_{2: \text { diterima }}$
\end{tabular}




\begin{tabular}{lllc}
$\mathrm{SI} \rightarrow \mathrm{BI}$ & 0,0567 & 0,8711 & $H_{3: \text { ditolak }}$ \\
$\mathrm{FC} \rightarrow \mathrm{BI}$ & 0,2543 & 2,3211 & $H_{4: \text { diterima }}$ \\
$\mathrm{PV} \rightarrow \mathrm{BI}$ & 0,2412 & 2,1451 & $H_{5: \text { diterima }}$ \\
$\mathrm{HM} \rightarrow \mathrm{BI}$ & 0,0671 & 0,2315 & $H_{6: \text { ditolak }}$ \\
$\mathrm{H} \rightarrow \mathrm{BI}$ & -0.1543 & 1,9821 & $H_{7: \text { ditolak }}$ \\
\hline
\end{tabular}

Sumber: Data Penelitian , 2021

Hasil analisis SEM pada Tabel 4, dengan taraf signifikancy 5 persen menunjukkan hipotetis pertama $\left(H_{1}\right)$ di tolak yaitu performance expectancy tidak berpengaruh terhadap minat menggunakan layanan $p 2 p$ lending syariah. Hasil tersebut menunjukkan bahwa tingkat efektivitas, kecepatan dan kenyamanan layanan fintech $p 2 p$ lending syariah tidak mempengaruhi minat untuk mengunakan fintech $p 2 p$ lending syariah, hal ini dapat dikatakan bahwa bahwa semakin tinggi tingkat performance expextancy tidak mempengaruhi minat mengunakan layanan fintech $p 2 p$ lending syariah. Hasil penelitian ini sejalan dengan hasil penelitian Kwateng et al (2019), Nugroho et al (2017), Nurisha et al (2018), Gayatri et al (2017), Gozali Handayani \& Budiarto (2018). Hasil penelitian ini tidak sejalan dengan hasil penetian Zulhaida \& Giri (2017), Ramdhani et al (2017), Pertiwi Ariyanto (2017) yang menyatakan Performance Ekspectancy berpengaruh signifikan terhadap Behavior intention Hasil penelitian ini tidak sesuai dengan model UTAUT2 yang menyatakan bahwa performance xpectancy mempengaruhi minat untuk menggunakan layanan fintech $p 2 p$ lending syariah

Berdasarkan hasil analisis SEM maka hipotesis $\mathrm{H}_{2}$ diterima, yaitu Effort expectancy berpengaruh postif terhadap minat menggunakan layanan $p 2 p$ lending syariah. Hasil penelitian menunjukkan bahwa Effort expectancy yang diberikan kepada pengguna layanan fintech $p 2 p$ lending syariah maka akan meningkatkan minat penguna layanan tersebut. Kesimpulan hipotesis penelitian yaitu pengguna layanan fintech $p 2 p$ lending syariah memiliki persepsi bahwa mereka memiliki kemampuan dalam mempelajari dan mempergunakan layanan $p 2 p$ lending syariah dan mereka juga memiliki persepsi bahwa dengan mempergunakan layanan $p 2 p$ lending syariah memberikan kemudahan dalam memperoleh pinjaman karena prosedur dan syarat untuk mengajukan pinjaman tersebut mudah untuk dipenuhi. Hasil penelitian sejalan dengan hasil penelitian Zulhaida \& Giri (2017), Ramdani et al (2017), Faridhal (2019), Gayatri et al (2017) yang menyatakan bahwa effort expectancy bepengaruh terhadap behavior intention. Hasil penelitian ini tidak sejalan dengan hasil penelitian Nugroho et al (2017), Nurisha et al (2018) dan Budiartho (2018) yang menyatakan bahwa variabel effort expectancy tidak berpengaruh dengan behavior intention. Hasil penelitian ini juga membuktikan bahwa salah satu faktor minat menggunakan layanan fintech $P 2 p$ lending syariah yaitu effort expectancy sesuai dengan model UTAUT 2

Pada Tabel 4, hasil analisis SEM maka hipotesis $H_{3}$ ditolak, yaitu social influence tidak bepenaruh terhadap minat menggunakan layanan $p 2 p$ lending syariah. Berdasarkan hasil tersebut dapat disimpulkan bahwa minat menggunakan layanan $p 2 p$ lending syariah tidak dipengaruhi oleh lingkungan keluarga, teman maupun lingkungan sosial lainnya untuk mendapatkan pinjaman. Hal lain yang mempengaruhi yaitu yang berasal dari sikap religious pengguna layanan $p 2 p$ lending syariah yang tidak menginginkan adanya unsur riba dalam pinjaman tersebut. Hasil penelitian ini sejalan dengan hasil penelitian 
Nurisha et al (2018), Faridha (2019) yang menyatakan bahwa variabel social influence tidak berpengaruh terhadap behavior intention. Hasil penelitian ini tidak sejalan dengan hasil penelitian Zulhaida \& Giri (2017), Chang et al (2019), Lubis \& Rahmawati (2019), Ramdhani et al (2017), Gayatri et al 92017) yang menyatakan bahwa social influence berpengaruh positif terhadap behavior intention. Hasil penelitian ini juga tidak sejalan dengan model UTAUT2 yang menyatakan social influence merupakan salah satu faktor yang mempengaruhi minat menggunakan layanan fintech $p 2 p$ lending syariah.

Hasil uji SEM pada Tabel 4, diperoleh hasil bahwa hasil $H_{4}$ diterima, facilitating condition berpengaruh positif terhadap minat menggunakan layanan $p 2 p$ lending syariah. Hasil dari nilai tersebut menunjukkan bahwa Facilitating condition yang tersedia mampu mempengaruhi minat menggunalan layanan fintech $p 2 p$ lending syariah. Kesimpulan dari hasil penelitian tersebut adalah fasilitas yang mendukung akan meningkatkan minat penggunaan fintech $p 2 p$ lending syariah, artinya pengguna fintech $p 2 p$ lending syariah telah disediakan sarana khusus yaitu kuota internet, aplikasi smart phone yang mudah dipahami dalam mempergunakan fintech $p 2 p$ lending syariah. Hasil Penelitian ini sejalan dengan hasil penelitian Chang (2019), Nugroho Kasim \& Sudarmawan (2018) yang menyakan bahwa facilitating condition berpengaruh terhadap behaviour intenton. Berbanding terbalik dengan hasil penelitian sebelunya yaitu hasil penelitian Zulhaidha \& Giri (2017), Nugroho et al (2017), Faridhal (2019), Gayatri et al (2017), Budiartho (2018) yang menyatakan facilitating behaviour tidak berpengaruh terhadap behavior intention. Hasil penelitian ini mendukung model UTATU 2 bahwa variabel facilitating condition merupakan salah satu faktor yang mempengaruhi behavior intention pengguna layanan fintech $p 2 p$ lending syariah

Hasil analisis SEM pada Tabel $4, \mathrm{H}_{5}$ diterima, Price value berpengaruh positif terhadap minat menggunakan layanan $p 2 p$ lending syariah. Banyak manfaat yang dirasakan oleh pengguna layanan $p 2 p$ lending syariah yaitu ketika pengguna layanan $p 2 p$ lending syariah mendapatkan pinjaman untuk kebutuhan usahanya maupun untuk kebutuhan pribadi tanpa menggunakan agunan dengan proses yang cepat. Hasil penelitian ini sejalan dengan hasil penelitian Nugroho et al (2017), Nurisha et al (2018), Chang et al (2019), Ahmed Kranti (2019) dan Budiarto (2018) yangmenyatakan price value berpengaruh terhadap behavior intention. Hasil penelitian ini tidak sejalalan dengan hasil penelitian Zulhaida \& Giri (2017), Ramdani et al (2017), Gayatri et al (2017), Lubis \& Rahmawati (2019) yang menyatakan bahwa price value tiidak berpengaruh terhadap behavior intention. Hasil penelitian ini mendukung model UTAUT 2 bahwa price value berpengruh terhadap behaviour intention pada pengguna layanan fintech $p 2 p$ lending syariah.

Hasil analisis SEM pada Tabel 4, menunjukkan bahwa hipotesis $H_{6}$ ditolak. Hedonic motivation tidak mempengaruhi minat pengguna layanan fintech $p 2 p$ lending syariah. Hedonic motivation seperti nilai religiunitas bukan merupakan faktor yang mempengaruhi minat untuk menggunakan layanan fintech $p 2 p$ lending syariah. Hasil penelitian ini sejalan dengan hasil penenlitian Zulhaida \& Giri (2017), Nugroho et al (2017), Nurisha et al (2017), Faridha (2019), gayatri et al (2017), Budiartho (2018), Chang (2019) yang menyatakan bahwa hedonic motivation tidak berpengaruh terhadap behavioral intention. Hasil 
penelitian ini tidak sejalan dengan hasil penelitian Ramdhani (2017), Lubis \& Rahmawati (2019) yang menyatakan bahwa hedonic motivation berpengaruh terhadap behavioral intention. Hasil penelitian ini tidak mendukung model UTAUT 2 yang menyatakan bahwa hedonic motivation berpengaruh terhadap behavioral intention pada minat penggunaan layanan fintech $p 2 p$ lending syariah.

Hasil uji analisis SEM pada Tabl 4, diperoleh hasil hipotesis $H_{7}$ ditolak. Artinya habit tidak berpengaruh terhadap minat menggunakan layanan fintech $p 2 p$ lending syariah. Habit di dalam penelitian ini seperti akad yang dipergunakan dalam peminjaman secara syar'i dan system bagi hasil sehingga penggunmenghindari pinjaman yang mengandung unsur riba tidak mempengaruhi minat untuk menggunakan layanan $p 2 p$ lending syariah. Hasil penelitian ini sejalan dengan hasil penelitian Zulhaida \& Giri (2017), Nugroho et al (2017), Nurisha (2018), Budiartho (2018) yang menyatakan bahwa habit berpengaruh terhadap behavior intention. Hasil penelitian ini berbanding terbalik dengan hasil penelitian Ramdhani et al (2017), Faridhal (2019), Gayatri et al (2017), Chang et al (2019), Lubis \& Rahmawati (2019) yang menyatakan bahwa variabel habit berpengaruh terhadap behavior intention penggunaan layanan suatu system informasi. Hasil penelitian ini bertolak belakang dengan teori UTAUT 2 yaitu habit merupakan salah satu faktor yang mempengaruhi behavior intention penggunaan layanan fintech $p 2 p$ lending syariah.

\section{SIMPULAN}

Variabel harapan kinerja (performance expectancy) tidak berepengaruh terhadap minat menggunakan layanan fintech peer to peer lending syaraiah, variabel usaha (effort expectancy) berepengaruh positif terhadap minat menggunakan laynan fintech peer to peer lending syariah, variabel pengaruh social (social influence) tidak berepengaruh terhadap minat menggunakan layanan fintech peer to peer lending syariah, varibel kondisi memfasilitasi (Facilitating condition) berpengaruh postifterhadap minat menggunakan layanan fintech peer to peer lending syariah, varibel price value berpenaruh positif terhadap minat menggunakan layanan fintech peer to peer lending syariah, Variabel hedonic motivation tidak berepengaruh terhadap minat menggunakan layanan fintech peer to peer lending syariah dan varibel habit berpengaruh negative terhadap minat menggnakan laynan fintech peer to peer lending syaraih. Keterbatasan waktu dalam penyebaran data kuesioner jangka waktu hanya satu bulan yaitu selama bulan Desember sehingga hasil penelitian kurang relevan dan Peneliti mengabaikan variabel moderasi seperti umur, pengalaman dan jenis kelamin.

Peneliti selanjutnya menambah jangka waktu penelitian lebih diperpanjang lagi sehingga jumlah responden akan lebih besar dan hasil penelitian lebih akurat dan peneliti dapat mempergunakan variabel moderasi seperti umur, pengalaman dan jenis kelamin. Fitur aplikasi lebih disederhanakan sehingga para pengguna lebih mudah untuk memahami pengunaan layanan $p 2 p$ lending syariah dan meningkatkan pelayanan sehingga para pengguna layanan $p 2 p$ lending syariah merasakan kenyaman akan bercerita kepada orang lain dan pada akhirnya akan mempengaruhi orang lain untuk mempergunakan layanan tersebut. 


\section{REFERENSI}

Abdillah, W., Hartono, (2015). Partial Least Square (PLS). Penerbit Andi. Yogyakarta.

Agustin, Henri, Mulyani. Erly. (2018). The Aceptance and Use of E-Leaning System Among Accountuing Lectures in State and Private University in Padang: An

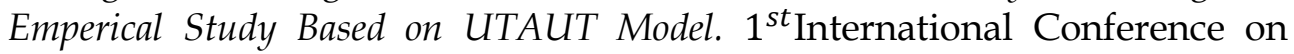
Economic Education, Economic Business and Management Accounting and Enterpreneurship (PICEEBA). Padang. 6-13

Alkhowaiter, W.A. (2020) Digital Payment and Banking Adoption Reseaarch In Gulf Countries; A Systematic Literature Review, International Journal Of Information Management

Alalwan, A. A Dwivedi, Y.K Dan Rana. N.P (2017) Factors InfluencingAdaption of Mobile Banking By Jourdanian Bank Customer: Extending UTAUT2 With Trust. International Journal of Information Management 37 (3), p 9110.

Amrullah, A \& Priyono. A (2018). Integrasi Aspek Risiko dalam Model Unified Theory of Acceptance and Use of Tchnology untuk menganalisis Penerimaan Teknologi go-Ride. Jurnal Ilmiah Manajemen, 3 (1): 33-49

Aries Andrianto. (2020). Faktor Yang Mempengaruhi Behaviour Intention Untuk Penggunaan Aplikasi Dompet Digital Menggunakan Model UTAUT2. Jurnal Ilmiah Ekonomi isnis Volume 25 (2)

Ascaryo. Putro. Hendratmoko. (2019). Faktor-Faktor Yang Mempengaruhi Individu Dalam menggunakan Peer to Peer Lending dan Equity Crowd Funding di DKI Jkarta. Manajemen Keungan. Vol 1. 1-11

Baihaqi, Jadzil (2018). Financial Technologi Peer to peer lending Berbasis syariah di Indonesia, Journal of Sharia Economic Law Vol 1 (2).

Brown. S.a and Ventakesh.V. (2005). A Model of Adoption of Technology In The Hausehold A base Ine Model Test And Extention Incorporating Hausehold Life Cycle. MIS Quartely. Volume 29 (3)

Budiato,R. (2018). Analisis Faktor adopsi Aplikasi Mobile Berdasarkan Pengalaman, Usia dan Jenis Kelamin Menggunakan UTAUT2. Jurnal Ilmiah Teknologi Sistem Informasi, Volume 32 (2)

Cao, Q. \& Niu, X. (2019). Integrating Contex_Awareness and UTATUT to explain Alipay User Adoption. International Journal of Indstrial Ergonomics: 69:913

Cai, S, Lin,, X, Xu, D., Fu, X .(2016). Judging online Peer to Peer lending behaviour. A Comparison of Firs time and repeated Borrowing RequetsInformation and management. 53 97). 857-867

Chang, C.M. Liu L.W Huang H.C., Hsieh, H.H. (2019). Factors Influenching Online Hotel Booking : Extending UTAUT2 with Age, Gender and Experience As Moderators. Information, Volume 10 (281)

Chuang, Lui dan Kao. (2016). The Adoptionof FintechService. TAM Prespective International Journal of Management and Administrative Science. Vol 3. ISSN:2225-7225

Enaizan.B. Mohammed, A.G. Alnoor, A., Alabbodi. A.S and Enaizan, O. (2019). Custome Acceptence Of Mobile Marketing in Jordan: An Extended 
UTAUT2 Model With Trust and Risk Factors, International Journal Of Engineering Business management. Volume 11

Faridhal, M. (2019). Analisis Transaksi Pembayaran Non Tunai melalui e Walet: Prespektif dari Modifikasi Model UTAUT2. Jurnal Ilmiah Mahasiswa FEB Universitas Brawijaya. Volume 7 (2)

Financial Bisnis.com, (2020). Perkembangan Peer to Peer lending syariah tahun 2020.

Gayatrie, M.S. A.Kusyati, A saputra M.C. (2017). Analisis Penerimaan OS Windows 10 dengan UTAUT2, Jurnal Pengembangan Teknologi Informasi dan Ilmu Komputer. Volume 1 (6)

Guo H, et al. (2015). Factors Influenching The User Acceptance of Alipay. Journal Conrefence of Economy, Management and Education Technology (ICEMAET) 244-347

Ghozali, Imam. (2013). Aplikasi Analisis Multivariate dengan program IBM SPSS 21 Up date PLS Regresi, Semarang: Badan Penerbit Universitas Diponegoro.

Hartono, J dan Abdillah, W. (2014). Konsep dan Aplikasi PLS untuk penelitian Empiris dalam penelitian Bisnis, Yogyakarta. STIM YKPM

Kontan.co.id. Perkembangan peer to peer lending 2019-2020

Lee, W and Shin, (2019) An Emperical Study Of Consumer Adoption Of Internet of Things service International Journal Of Engineering and Technology Information. Volume 9 (1)

Lenz, R (2016). Peer to Peer Lending: Opportunities and Risks, European Journal Of Risk and Regulation 7 (4) 688-700

Liu,G-S dan P,T (2016). A Study of factors Affecting The Intention to Use Mobile Payment Services in Vietnam, Economic World. 4 (6); 249-273

Lubis, M. F. T. dan Rahmiati. (2019). User Acceptence Online Travel agents Agent For Millenials and Gen Z. Jurnal Mutiara Ilmu Ekonomi dan Bisnis. Volume 32 (2)

Kwateng, K. O, Aiemo, K. O. dan Appiah. (2019). Acceptance and Use of Mobile banking; An Aplication of UTAUT2. Journal of Enterprise Information Management. Volume 32 (1)

Nugraha,B .S., Idqan Fahmi., Tanti Novianti. (2020). Kajian Faktor Yang Mempengaruhi Adopsi Sistem Pinjaman.Jurnal Manajemen Teknologi. Volume 19 (1)

Nugroho. P. Winarno, W. W., dan Hartanto R. (2017). Faktor-Faktor Yang Mempengaruhi Niat menggunakan Mobile Payment dengan Pendekatan Extended The Unified Theory Of Acceptance and Use of Technology. Prosiding Seminar Nasional CITEE 2017

Nuriska, A., Assakdiah, S., \& Setyawan, R. R. (2018). Factors Effecting behavior intention in Using Go Pay With The UTAUT2. Muhammadiyah International Journal Of Economic and Business. I (2)

Oliveira, T., Thomas, M., Baptista, G., dan Compos, F (2016). Mobil Paymen: UnderstandingThe Determinants Of Customer Adaptionand Intentionto Recommendedthe Tecnologi Computerin Human Behaviour 61 p 404-414 
Otoritas Jasa Keuangan. (2016). Peraturan Otoritas Jasa Keuangan POJK No 77/POJK.01/2016Tentang pinjam MeminjamUang berbasis Teknologi Informasi. Diakses dari www.ojk.go.id.

Otoritas Jasa Keuangan. (2019). Ihktisar Keuangan Fintech (Peer to Peer Lending Agustus 2019). Diakses dari https://www.ojk.go.id/kanal/iknb/data

Pertiwi, N.W, Ariyanto D. (2017). Penerapan Model UTAUT2 Untuk Menjelaskan Minat dan Perilaku Penggunaan Mobile Banking di Kota Denpasar. EJurnal Akuntansi Universitas Udayana. Volume 18 (2)

Priyatmoko., Nugroho, Wing., Wahyu, W., dan Rudi Hartanto. (2017). FaktorFaktor Yang Mempengaruhi Niat menggunakan Mobile Payment Dengan Pendekatan Extended The Unified Theory of Acceptance and Use of Technology. Yokyakarta: Departemen Teknik Elektro dan Teknologi Informasi. UGM

Putri, D. A., Harsono, dan L. D., (2017). The Use Modified Unified Theory Of Acceptance and Use of Technology 2 model To Analyze Factors Influencing Continuance Intention of e paymen Adoption (A Case Study of Go Pay From Indonesia). Injternational Journal of Science and Research. Volume 6 (11).

Raman, A., \& Don Y. (2013). Preservice Teachers Acceptance Of Learning Management Software: An Application of The UTAUT2 Mode. International Education Studies. Volume 6 (7)

Ramdhani, A. B., Rachmawati, \& Prabowo F. S. A. (2017). Pengaruh Adopsi Teknologi Layanan Uang Elektronik Telkomsel Cash menggunakan Pendekatan UTAUT 2e Proceding Management, Volume 4 (1)

Riski, Nanda, M., Ari Kusyanti, Himawati., \& Aryadita. (2018). Analisis Faktorfaktor Yang mempengaruhi Niat Menggunakan E Commece XYZ Menggunakan Model UTATUT. Jurnal Pengembangan Teknologi Informasi dan Ilmu Komputer. Vol 2 (7) 2584-2593

Sekaran, V and Bougie R. (2016). Reseacrh Methods For Business A Skill Building approach Seventh Edition. In John and Wiley and Son Ltd.

Sivathanu, B. (2018). Adoption of Digital Paymen Systems in The Era Demonetization in India, Journal of Science and technology Policy Maagement.

Sugiono (2014). Metode Penelitian Pendidikan Pendekatan Kuantitatif, Kualitatif dan $R$ \&D

Sugiono (2018). Metode Penelitian Kuantitatif, Kualitatif, R\&D In Bandung: Alfabeta.

Suwandi. M. A \& Aziz E. (2018). Faktor-Faktor Yang Mempengaruhi Penggunaan E-Money pada Generasi Millenials (Studi Kasus Pada Mahasiswa S1 IPB) E Proceeding of Management. 5 (3): 3104-311

Venkatesh, V Morris M. G., Davis G. B. dan Davis F D. (2003) User Acceptence of Information Technology: Toward a Unified view.MIS Quarterly. 27 (3) 425478

Veronica., Yuniarti., Wiwik H., dan Ekowati. (2019). Faktor-Faktor Yang Mempengaruhi Minat Penggunaan Financial Technologi Peer to Peer lending https://pdfs.semakticscholar.org 
Wahyu. Meiranto. 2012. Analisis Faktor-Faktor Yang Mempengaruhi minat Pemanfaatan dan Penggunaan Teknology Pembayaran Elektronik Bergerak Dengan Menggunakan Model UTAUT. Jurnal Akuntansi Indonesia Vol 1. 50-60

Yum, H, Lee ., Chae, M. 2012. Electronoc Commerce Researc and application From The Wisdom Of Crowds to my Own Judment in Micrifinance Through online Peer to Peer lending flatform elctronic Commece. Research and Aplication, 11(5) 469-483

Zhou.T. 2013. An Emperical Examinationof Continuance Intention of Mobile Paymen service decision Support systems https://doi.org/10.1026/j.dss.201210.034

Zhu, Z (2018), Safety promise, moral hazzard and financial Supervision: Evidence from peer to Peer Lending, Finance Researc Letters 27 (March) 1-5 https:/ / keuangan.kontan.co.id 